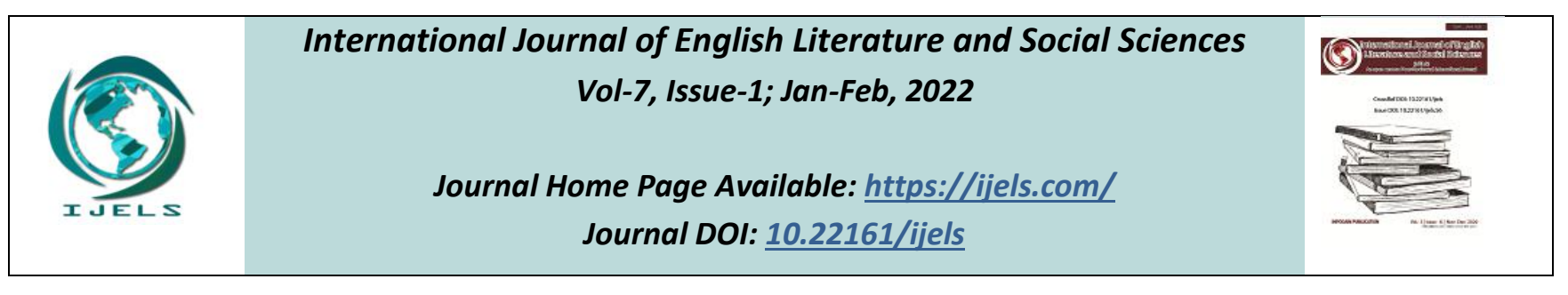

Peer-Reviewed Journal

\title{
Feminism in Alice Walker's The Color Purple
}

\author{
Emmanuel Simparinka
}

English Lecturer, Rwanda Polytechnic / IPRC Tumba, Rwanda.

Email: simpemmano@gmail.com

Received: 12 Dec 2021; Received in revised form: 10 Feb 2022; Accepted: 18 Feb 2022; Available online: 24 Feb 2022

C 2022 The Author(s). Published by Infogain Publication. This is an open access article under the CC BY license

(https://creativecommons.org/licenses/by/4.0/).

\begin{abstract}
This study under the title "Feminism in Alice Walker's 'The Color Purple"” studies different aspects of feminism highlighted in The Color Purple and tries to understand the status of black women in patriarchal American society. This study is guided by two questions which ask whether black women are victims of sexism in American society and how women can free themselves from man's domination. Besides, key concepts such as feminism,feminist theory, sexism and sisterhood are defined. Two types of feminism, namely liberal feminism and radical feminism are discussed in this study. Since this research is qualitative, data and data sources are also qualitative and they are collected and analysed qualitatively using psychological, historical and feminist approaches. After a thorough analysis of the novel, it is concluded that black women are victims of sexism in American society and that through sisterhood women can free themselves from man's domination.
\end{abstract}

Keywords-Feminism, feminist theory, patriarchy, sexism, sisterhood.

\section{INTRODUCTION}

The Color Purple is a novel written by Alice Malsenior Walker. She was born to Willie Lee Walker and Minnie Tallulah Grant Walker in the rural community of Eatonton, Georgia on February 9, 1944. She was the youngest of eight children, five boys and three girls. When she was eight years old, Walker was blinded in one eye when her brother accidentally shot her with a BB gun. The incident was traumatic and Alice Walker changed into a shy, solemn and solitary girl. After high school, Walker went to Spelman College in Atlanta on a full scholarship in 1961 and transferred to Sarah Lawrence College near New York City in 1963. After graduating in 1965, Walker became interested in United States civil rights movement in part due to the influence of activist Howard Zinn, who was one of her professors at Spelman College.

As far as her writing career is concerned, Walker has written poetry, short stories novels, essays and anthologies. In 1983, Walker became the first African American woman to win the Pulitzer Prize for Fiction for her novel The Color Purple. She also won the National Book Award for Fiction for The Color Purple in 1983, Honorary Degree from the California Institute of the Arts in 1995, Domestic Human Rights Award from Global Exchange in 2007, and more others.

However, my research paper under the title "Feminism in Alice Walker's The Color Purple" explores the rights of black women in American society before and at the time of its publication. This is highlighted through black female characters such as Celie, Nettie, Sofia and Shug Avery. Celie, being raped by his stepfather and then being sent to be married to a harsh husband against her will illustrates the ill-treatment of women and that they were in one way or another, the male's objects of pleasure.

\section{Statement of the problem.}

Many writers have produced works that explored the conditions of women under patriarchal societies. The image of women in literary works has been portrayed in terms of their relationship with man in a world obviously dominated by men. In thiscontext, Beauvoir (1949) said:

La femme a toujours été, sinon l'esclave de l'homme, du moins sa vassale; les deux sexes ne 
se sont jamais partagé le monde à égalité; et aujourd'hui encore, bien que sa condition soit évoluée, la femme est lourdement handicapée. En presque aucun pays son statut légal n'est identique à celui de l'homme et souvent il la désavantage considérablement (p. 20).

Woman has always been either the slave of the man or his vassal. These two sexes did not share the world equally, and even today, although her condition is developing, woman is highly handicapped. In almost all countries her legal status is not the same as that of man and she is considerably disadvantaged. [Translation is mine].

Hook (1994, as cited in Torfs, 2008) asserts that patriarchy, the institutionalized structure of male dominance, encourages males of all races and classes to define their masculinity by acts of physical aggression and coercion toward others, women and children.

However, Alice Walker in her "The Color Purple" portrayed the condition of black women in American society. She highlighted that women were dominated and ill-treated by men and that they didn't have any right. "A girl is nothing to herself; only to her husband can she become something" (Walker 1982, p. 144).

Finally, this study seeks to explore the way women are victims of the society dominated by the men and what women should do to get rid of their everyday ill-treatment.

\section{Research objectives}

This study seeks to explore the way women are victims of the society dominated by the men and what they should do to get rid of their everyday ill-treatment. To attain this aim, two questions were asked:

1. Are black women victims of sexism in American society?

2. How did black women free themselves from man's domination?

\section{Purpose of the study}

In this study I will go through the content of Alice Walker's The Color Purple. In this regard, I will consider the message conveyed by characters especially Celie, the central character. The latter being a black woman, will be of much importance in highlighting the way black women are victims of sexism in American society. Besides, the interaction and relationship between female characters and male characters will help me to demonstrate the conditions in which black American women lived, and the way they have fought for their freedom.

\section{Justification and significance of the study}

This research is directed to Alice Walker's “The Color Purple" because of different reasons. The first reason is that I am interested so much in American literature, especially African American literature. The second reason is that Alice walker is easy to read, and the third reason is that this writer is, in one way or another, linked to African past and history.

In addition, the fact that feminism is flourishing nowadays in Africa in general and in Rwanda in particular, pushes me to direct my research in feminism so that Rwandans would get some information about the way women of the other side of the world lived. This is why I have decided to consider Alice Walker's "The Color Purple" my case study.

Finally, I was convinced that researching on feminism would help today's people to have a good view of the world as far as women's issue is concerned. So, this is helpful since the information about the past is necessary and important to prepare a good future.

\section{LITERATURE REVIEW}

Historically, the term feminism, was first used by the French dramatist Alexendre Dumas the Younger, in 1782 in a pamphlet, L'Homme-femme, to designate the then emerging movement for women's rights(Encyclpeadia Americana, 1960).

Different writers have also tried to define the term in different ways: Feminism is the belief in social, economic, and political equality of the sexes(Brunell \& Burkett, 2021). It is a political label showing support for the aims of the new women's movement which emerged in the early 1960 's. Throughout its long history, feminism has sought to disturb the patriarchal culture and to assert a belief in sexual equality as well as to eradicate sexist domination in transforming society. Emphasis was on women gaining greater individual freedom (Masuku, 2005). Feminismrefers to political, social, and intellectual movements working towards the goal of equality for individuals of all genders(Eidinger, 2020). It can also mean black women's movement committed to securing and defending rights and opportunities for women that are equal to those of men(Woodford, Jackson \& Gillard, 2003)

Feminism related terms have also been discussed by different authors as follows: Feminist theory is a major branch within sociology that shifts its assumptions, analytic lens, and topical focus away from the male viewpoint and experience toward that of women. In doing so, feminist theory shines a light on social problems, trends, and issues that are otherwise overlooked or 
misidentified by the historically dominant male perspective within social theory(Crossman, 2020). Sexism is the belief that the members of one sex are less intelligent, able, skilful, etc. than the members of the other sex, especially that women are less able than men(Woodford, Jackson, \& Gillard 2003). Historically, sexism has been male-driven and accompanied by a belief in the inferiority of women. Sexism as a social system gives all powers to men and makes women their subordinate. It undermines women values and practices and encourages male dominance and control of economic, political and social institutions. Sexism functions through individual beliefs and practices, institutions, images, and ideas, and is enforced by economic structures, violence, and homophobia(Redmond, 2008)

Sisterhood is a strong feeling of companionship and support among women who are involved in action to improve women's rights. (Woodford, Jackson \& Gillard, 2003). Feminist scholars and activists frequently used the term "sisterhood" invoking powerful notions of female solidarity and interconnections across cultures and nations albeit through the creation and representation of unequal feminists and female subjects. Implicit and explicit divisions are implied in the discourse of "global sisterhood" between "feminists" and "other women" where the assumption seems to be that feminists inhabit one world (the Western one) whereas other women live elsewhere and are not feminists or unequally feminists. (Chowdhury, 2006)

Feminism has different types. Liberal feministsargue that women as individuals are equal to men, and should therefore be given equal opportunities as men to pursue their own interests, that the state should limit its interference in society, that society's structure around the nuclear family is ideal, and should not be altered by the state, that women should maintain their roles as wives and mothers, and attain equality within this structure. They believe that this can be achieved by allowing women to gain an education, and giving them equal opportunities to pursue their career Bryson (2003 as cited in Awad, Eldon\& Pace, n.d).Liberal feminism is for gradual reforms through advocacy for equal rights for all, and laws and policies that promote equality. (Samkange, 2015).

On the other side, Radical feminism is a perspective within feminism that calls for a radical re-ordering of society in which male supremacy is eliminated in all social and economic contexts, while recognizing that women's experiences are also affected by other social divisions such as in race, class, and sexual orientation (Wikipedia). Radical feminism grew out of the recognition that society had been structured to the disadvantage of women, for their subjugation and the related empowerment of men, all the while working for the eradication of domination and elitism in all human relationships(Egan, 1999). It views patriarchy as dividing societal rights, privileges, and power primarily along the lines of sex, and as a result, oppressing women and privileging men (Lewis, 2020).

In fact, different researchers and critics have conducted research on The ColorPurple and have drawn different conclusions. The Color Purple depicts the life of a black girl, Celie who despite poverty, illiteracy, physical and mental exploitation transcends her plight through selfawareness to gain respectable place in the American society(Radjuru, 2014). The Color Purple is a novel that wonderfully portrays the gradual forming of a new black woman, Celie, who evolves from patriarchal oppression to awakening and independence. Celie a black poor and uneducated African American girl is able to change her situation. She is a symbol of hope that impresses the readers by her strength, faith and courage(Baga, 2010).

Walker portrays women characters who crave the freedom from brutality and complex systems of oppression. The complete perfection in the novel is that it does not provide an imaginary world; rather it brings out the real colour of the black women and their life style in the oppressed community, which further oppresses them! Walker brings out the voice of the voiceless through the protagonistCelie within the Black society (Dhivya, 2016). The Color Purple records important hallmarks in feminist literary criticism. Walker not only attacks patriarchal oppression and claims the submerged voice of women. One important thing that she also calls into question is the polarity between femininity and masculinity. Walker expresses her concern about gender roles and gender dynamics in her characterization and plot development(Hsiao, 2008).

However, this paper highlights how black women were victims of sexism in American society and that the oppressed female overcame their frustration and got empowered through their sisterhood.

\section{METHODOLOGY}

The research design refers to the overall strategy that you choose to integrate the different components of the study in a coherent and logical way, thereby, ensuring you will effectively address the research problem; it constitutes the blueprint for the collection, measurement, and analysis of data(De Vaus, 2001). This research is designed as a qualitative research and the main source of data is a novel entitled The Color Purple by Walker, published in 1982. The secondary data sources are to be taken from books, article and information either written or electronic and the 
other related sources to support the analysis of the main data source.

Data analysis is, simply put, the process of discovering useful information by evaluating data(Stevens, 2021). It is a method in which data is collected and organized so that one can derive helpful information from it. In other words, the main purpose of data analysis is to look at what the data is trying to tell us(Whiting, 2021). However, since this study was based on a text analysis, some techniques of literary analysis were selected and chosen to be used in the data analysis.

The researcher usedthree data analysis approaches. The first waspsychological approach. This approach analyses the author of the work or a character in his work. It helps the readers understand the motivations of the writer as well as the characters(Hasa, 2016). The second was feminist approach. Thisapproach examines the ways in which literature reinforces or undermines the economic, political, social, and psychological oppression of women(Tyson, 2006). It recognizes that literature both reflects and shapes stereotypes and other cultural assumptions(Napikoski, 2020). The third and last was historical approach. This approach involves looking beyond the literature at the broader historical and cultural events occurring during the time the piece was written. An understanding of the world the author lived in (events, ideologies, culture, lifestyle etc.) allows for a more comprehensive understanding of the work(Goodwin University, 2022)

\section{DISCUSSION}

Female characters in The Color Purple have been sexually abused by different men at different times. The first woman to be sexually abused is Celie's mother. Fonso didn't consider her feelings, even when she was very sick and half dead, he wanted to have sexual intercourse with her instead of nursing her. Celie highlights it in her first letter to God. The letter says:

Dear God, ... Last spring after little Lucious come I heard them fussing. He was pulling on her arm. She say It too soon, Fonso, I ain't well. Finally he leave her alone. A week go by, he pulling on her arm again. She say Naw, I ain'tgonna. Can't you see I'm already half dead, an all of these chilren (Walker, 1982, p. 11).

Celie, the main character of the novel underwent sexual abuse too. When FonsoFailed to have sexual intercourse with her wife, she abused her stepdaughter. Her mother was not home. This is really unbelievable since the role of a father would be protecting all the members of the family instead of abusing them. In a letter written to God, Celie highlights that she was raped by her stepfather. She says:
She went to visit her sister doctor over Macon. Left me to see after the others. He never had a kine word to say to me. Just say Yougonna do what your mammy wouldn't. First he put his thing up gainst my hip and sort of wiggle it around. Then he grab hold my titties. Then he push his thing inside my pussy. When that hurt, I cry. He start to choke me, saying You better shut up and git used to it. But I don't never git used to it (Walker, 1982, p. 11).

Celie was not only raped by her stepfather but also by her husband: "Mr. come git me to take care his rotten children. He never ast me nothing bout myself. He clam on top of me and fuck and fuck, even when my head bandaged. Nobody ever love me, I say" (Walker, 1982, p. 109).

Another female character to be sexually abused is Mary Agnes popularly known as Squeak. She was raped by her uncle when trying to free Sofia from jail:

He took my hat off, say Squeak. Told me to undo my dress. My God, say Odessa, and he your uncle. He say if he was my uncle he wouldn't do it to me. That be a sin. But this just little fornication. Everybody guilty of that (Walker, 1982, p. 95).

In the Color Purple Fonso abused Celie physically. In a letter written to God, Celie explained the issue:

Dear God, He beat me today cause he say I winked at a boy in church. I may have got somethin in my eye but I didn't wink. I don't even look at mens. That's the truth. I look at women, tho, cause I'm not scared of them. (Walker, 1982, p. 15).

Fonso didn't beat Celie only once. He used to beat her whenever he wished. But even though he beat her he couldn't stop himself from having sex with her. The following quote explains fully Celie's misfortune:

I ast him to take me instead of Nettie while our new mammy sick. But he just ast me what I'm talking bout. I tell him I can fix myself up for him. I duck into my room and come out wearing horsehair, feathers, and a pair of our new mammy high heel shoes. He beat me for dressing trampy but he do it to me anyway (Walker, 1982, p. 17).

Celie's abuse didn't stop. After her marriage they continued abusing her. In a letter addressed to God she wrote:

Dear God, I spend my wedding day running from the oldest boy. He twelve. His mama died in his arms and he don't want to hear nothing bout no 
new one. He pick up a rock and laid my head open. The blood run all down tween my breasts. His daddy say Don'tdo that! But that's all he say (Walker, 1982, p. 21).

Celie being beaten by her husband is another element illustrating negative impact of sexism This confirms the idea that women had no rights and that men had the right to ill-treat their wives: "Dear God, Harpo ast his daddy why he beat me. Mr. say, Cause she my wife. Plus, she stubborn. All women good for - he don't finish" (Walker, 1982, p. 30).

Celie is not the only female character of the novel to be physically abused. Sofia, Harpo's wife underwent this kind of abuse. And this is highlighted in the following letter that Celie wrote to God:

Dear God, Harpo want to know what to do to make Sofia mind. He sit out on the porch with Mr. __. He say, I tell her one thing, she do another. Never do what I say. Always backtalk. .....You have to let 'em know who got the upper hand. Nothing can do that better than a good sound beating (Walker, 1982, p. 42).

Fonso has abused Celie not only sexually but also morally and verbally. This form of abuse is expressed in the following part of a letter that Celie wrote to God:

Dear God, He act like he can't stand me no more. Say I'm evil an always up to no good. He took my other little baby, a boy this time. But I don't think he kilt it. I think he sold it to a man an his wife over Monticello. I got breasts full of milk running down myself. He say Why don't you look decent? Put on something. But what I'm sposed to put on? I don't have nothing (Walker, 1982, p. $13)$.

Celie was also verbally abused by her husband. When Celiediscoverd that he has been hiding her sister's letters and decided to leave him in order to live with Shug Avery, he insulted her:"You'll be back, he say. Nothing up North for nobody like you. ....You ugly. You skinny. You shape funny" (Walker, 1982, p. 186). Mr. went on cursing his wife: "Who you think you is? he say. You can't curse nobody. Look at you. You black, you pore, you ugly, you a woman. Goddam, he say, you nothing at all" (Walker, 1982, p. 187).

Alice walker explains to the readers that women don't have the same rights as men and men deprive women their rights. This is highlighted through Fonso, who refused Celie her right to go to school. "The first time I got big Pa took me out of school. He never care that I love it" (Walker, 1982, p. 19). Another fact that unveils women's oppression is that men could divorce them anytime, especially when they got older to replace them by younger ladies. There was no law to protect them: "She up and left me, you know. Went back to her folks. Yeah, he say, you would remember May Ellen. Why she leave? I ast. He laugh some more. Got too old for me, I reckon" (Walker, 1982, p. 166).

Women in the Color Purple were not allowed to choose their partners. As indicated in a letter Celie wrote to God, Nettie was refused the right to marry Mr. ___ : "Dear God, Mr. __ finally come right out an ast for Nettie hand in marriage. But He won't let her go" (Walker, 1982, p. 16).

Even though $\mathrm{Mr}$. wanted Nettie's hand, her father insisted that Nettie was too young and that he would offer him Celie instead. Fonso had raped Celie so many times, had impregnated her two times and took away her two children, a boy and a girl. Then he wanted Mr. to marry her because he knew she was spoiled and that he was no longer in need of her. So he told Mr. ___ : "She the oldest anyway. She ought to marry first. She ain't fresh tho, but I spect you know that. She spoiled. Twice. But you don't need a fresh woman no how" (Walker, 1982, p. 17).

Sofia was also in love with Harpo, but Mr.

Harpo's father's interference troubled the couple: "Young womens no good these days, he say. Got they legs open to every Tom, Dick and Harry. ... No need to think I'm gon let my boy marry you just cause you in the family way" (Walker, 1982, p. 38).

Shug Avery was also denied her right to marry a man of her choice. This is what she told Celie:

His daddy told him I'm trash, my mama trash before me. His brother say the same. Albert try to stand up for us, git knock down. One reason they give him for not marrying me is cause I have children. But they his, I told old Mr.

(Walker, 1982, p.117).

However, these kinds of marriage arrangements which prevented women from choosing their partners affected both women and their families negatively. This is because women and their husbands were not linked by love, but by their fathers' interests. For instance, Mr. . lovedShug Avery and wanted her to be his wife. But after his father's refusal, he married Annie Julia. This marriage was a failure because neither Mr. ___ nor Annie Julia loved his / her partner. After the deaf of Annie Julia, Mr. ___ felt in love with Nettie and Nettie loved him too. This time Nettie's father interfered and prevented them to get married. Then Mr. __ was married toCelie. This marriage was also a failure because Celie was not loved and was considered as an object of pleasure.

Another case that justifies the negative side of women's imposed marriages is that of Sofia. Harpo loved Sofia and Sofia loved him. However, Sofia's abuse from her father in 
law kept growing since he knew they were in love. After a long struggle they were married but $\mathrm{Mr}$. used all his power to cause their divorce. After they had divorced, Harpo was married to Squeak, a girl who obeyed him blindly. This is what his father wanted Harpo to do, but again the marriage became a failure because of the lack of love. Harpo still loved Sofia instead of Squeak even though they were divorced.

Woodford, Jackson \& Gillard (2003) define sisterhood as a strong feeling of companionship and support among women who are involved in action to improve women's rights. In the color Purple, sisterhood between Celie and Nettie is expressed through their companionship. The problem of one of them was automatically the concern for another. When Celie's mother died, Celie was not at ease. She was afraid that Fonso, her stepfather, could rape her little sister, Nettie. In a letter written to God, she said: "I keep hoping he fine somebody to marry. I see him looking at my little sister. She scared. But I say I'll take care of you. With God help" (Walker, 1982, p. 13).

Celie being concerned about Nettie's security is clear in the novel. Celie did whatever she could to protect Nettie against Fonso, who would rape her anytime he got the opportunity: "Sometime he still be looking at Nettie, but I always git in his light. Now I tell her to marry Mr.

don't tell her why. I say Marry him, Nettie, an try to have one good year out your life. After that, I know she be big" (Walker, 1982, p. 15).

Sisterhood between Celie and Nettie was so strong that Celie decided to offer herself to Fonso to protect her. This is explained in a letter Celie wrote to God. It read: "Dear God, I ast him to take me instead of Nettie while our new mammy sick. .... I tell him I can fix myself up for him. .... He beat me for dressing trampy but he do it to me anyway" (Walker, 1982, p. 17).

However, Nettie was not lucky to have Celie beside her. Celie was forced to marry $\mathrm{Mr}$. Nettie stayed home with Fonso which made Celie uncomfortable. Celie told God her concern about Nettie as follws: "Dear God, ... But I don't cry. I lay there thinking bout Nettie while he on top of me, wonder if she safe" (Walker, 1982, p. 21).

Another fact that expresses the strong sisterhood between Celie and Nettie is that when Nettie was no more secured she fled to Celie. This also expresses their mutual assistance: "Dear God, Nettie here with us. She run way from home. She say she hate to leave our stepma, but she had to git out, maybe fine help for the other little ones. The boys be alright, she say (Walker, 1982, p. 25).

Celie was happy to live with Nettie. She was lucky to get another chance to protect her. But $\mathrm{Mr}$. Celie's husband wanted to make love with her. Nettie refused.
Then $\mathrm{Mr}$. ordered his wife that Nettie had to leave their home. Celie didn't let her go anyhow. She told her where to go because she thought she would be safe there. Nettie had left. But she was not peaceful since she knew Mr. __ was ill-treating Celie, her sister. So after finding shelter at Samuel's, she asked him to try to save Celie. This can be read in a letter she wrote to Celie. It said: "I asked Samuel if he would visit you and Mr. , just to see how you are. But he says he can't risk putting himself between man and wife, especially when he don't know them" (Walker, 1982, p. 121).

Celie and Shug didn't know each other before. They met for the first time at $\mathrm{Mr}$. when Shug was sick. However, Shug and Mr. had been in love for a long time before Celie was married to $\mathrm{Mr}$. They had decided to get married but because of sexist culture which made men control every body's life, especially women,Shug was denied her right to marry $\mathrm{Mr}$. She was accused of being a trash like her mother.

Shug was really a friend of Mr. , not a friend of Celie. Their only link was that of sisterhood. Celie had in mind that all women didn't have the same rights as men and that the common enemy for women was a man. So she didn't consider Shug her enemy. Then she started nursing her as indicated in the following part of letter she wrote to God: "I wash her body, it feel like I'm praying. My hands tremble and my breath short" (Walker, 1982, p. 53).

Celie felt a strong sisterhood in herself. This is explained through everything she did for Shug. It is very clear that she didn't nurse Shug only on her husband's order. But she nursed her willingly and healthfully. In a letter she wrote to God she explained that she considered Shug as her children or her mother. She said: "I work on her like she a doll or like she Olivia — or like she mama. I comb and pat, comb and pat" (Walker, 1982, p. 57).

Celie and Shug ties were very strong that Shug dropped the idea of leaving before she made sure that Mr.

would never thing of beating her. Celie expressed that in a letter she wrote to God. She said: "I won't leave, she say, until I know Albert won't even think about beating you (Walker, 1982, p. 77).

As days went on Shug and Celie's relationship hit the pick. Their sisterhood reached a maximum level and slept together as lovers, and made love! Celie noted it as follows:

She say, I love you, Miss Celie. And then she haul off and kiss me on the mouth. Um, she say, like she surprise. I kiss her back, say, um, too. Us kiss and kiss till us can't hardly kiss no more. Then us touch each other. I don't know nothing bout it, I say to Shug. I don't know much, she say. 
Then I feels something real soft and wet on my breast, feel like one of my little lost babies mouth. Way after while, I act like a little lost baby too (Walker, 1982, p. 109).

It was by the help of Shug that Celie discovered hidden letters that Nettie had been sending her: "Saturday morning Shug put Nettie letter in my lap. Little fat queen of England stamps on it, plus stamps that got peanuts, coconuts, rubber trees and say Africa. ... He been keeping your letters, say Shug" (Walker, 1982, p. 114).

Women in The Color Purple knew that they were oppressed by men. Some were ready to fight to get their rights while others were passive. However due to their sisterhood they helped each other and came up with one and only one solution to sexism which was fighting men who oppressed them.

At the beginning of the novel Celie was raped by her stepfather and she didn't fight. She was very passive and didn't tell it to anybody. What she did was simply wring letters to God. She believed that only God would help her end her problems. However, Nettie told her that she had to fight. Celie talked about this in a letter she wrote to God. She said: "Don't let them run over you, Nettie say. You got to let them know who got the upper hand. They got it, I say. But she keep on, Yougot to fight. You got to fight" (Walker, 1982, pp. 25-26).

Another person who asked Celie to fight sexism is Kate, Mr._'s sister. When she visited them, she realised that Celie had no right and that she was dominated by both his husband and his son, simply because she was a woman. So she invited her to fight for her rights. She said: "You got to fight them, Celie, she say. I can't do it for you. You got to fight them for yourself" (Walker, 1982, p. 29).

The first woman to fight sexism is Sofia, Harpo's wife. Celie had advised Harpo to beat Sofia so that she could respect men as Celie did. But when Harpo tried to beat her Sofia defended herself and beat Harpo as a little kid. In the novel it is said: “... Harpo his face a mess of bruises. His lip cut. One of his eyes shut like a fist. He walk stiff and say his teef ache. I say, What happen to you, Harpo? He say, Oh, me and that mule." (Walker, 1982, p. 43).

Another time Harpo wanted to show Sofia that she had to surrender and obey his orders as Celie did for her husband. But Sofia couldn't accept it. So they fought: "I open the door cautious, thinking bout robbers and murderers. Horsethieves and hants. But it Harpo and Sofia. They fighting like two mens" (Walker, 1982, p. 44).

Harpo didn't give up. He always thought of making Sofia surrender. He wanted a wife who would obey him as Celie obeyed his father. But this was very dangerous for him since Sofia was not a woman who could accept this kind of treatment. She wanted only a husband who could respect her. Not a husband who would oppress her. So, when Harpo tried to beat her again, she taught him a lesson. The lesson was the following: "I give him a hansker. He blow his nose, look up at me out of two eyes close like fists. What happen to your eyes? I ast. ... Sofia, he say" (Walker, 1982, p. 65).

Sofia was really a freedom fighter. She could not accept anyone humiliate her. She reacted on all attacks wherever they came from. One day she sassed Miss Millie and knocked down the Mayor, her husband, when they provoked her. The novel described the event as follows: "Mayor look at Sofia, push his wife out the way. Stick out his chest. Girl, what you say to Miss Millie? Sofia say, I say, Hell no. He slap her.... Sofia knock the man down" (Walker, 1982, p. 86).

Nettie was also a freedom fighter. She could not behave like Celie, her sister. She had resisted against Mr. 's need to sleep with her. When he ordered her out of his home, Nettie left. But Mr. followed her and tried to rape her. So Nettie fought and defeated the aggressor. Nettie told this in a letter she wrote to Cellie. She said: "Well, I started to fight him, and with God's help, I hurt him bad enough to make him let me alone. But he was some mad" (Walker, 1982, p. 119).

Finally, Celie changed her mind and decided to fight for her freedom like others. She changed her mind after discovering that Mr. had hidden letters that Nettie had been sending her. She had even thought of killing him but Shug opposed the idea. Yet, they decided to leave him and go to Memphis. Mr. ___ could not understand why Celie had decided to go and how she had changed her mind so suddenly. But Celie was determined to end her oppression. She told him: "You a lowdown dog is what's wrong, I say. It's time to leave you and enter into the Creation. And your dead body just the welcome mat I need" (Walker, 1982, p. 181).

Influenced by Celie's leave, Squeak, Harpo's wife decided to free herself from her husband's domination. She was married to Harpo after Sofia left him. Sofia had refused to be oppressed by Harpo and left him. Then, Harpo married Squeak who obeyed him blindly and who could not fight for her rights. As his father, Harpo was also surprised to hear that Squeak was leaving: "Finally, Squeak look at everybody from under her bangs. Me, she say. I'm going North" (Walker, 1982, p. 100). 


\section{CONCLUSION}

After a thorough analysis ofThe Color Purple, we learnt, through female characters, that black women were victims of sexism in American society. First, women were victims of sexual abuse. This is the case of Celie's mother whose husband pulled her to bed for sex when she was half dead; Celie, the main character, who was raped twice by her father and Mary Agnes popularly known as Squeak who was raped by her uncle when she tried to free Sofia from jail.

Apart from sexual abuse, women underwent physical abuse. Celie was beaten by her father after false accusation of winking at a boy in the church. Her husband beat her because she was not Shug Avery, the wife of his choice. Celie was also attacked by her stepson and injured on the head, but her husband didn't punish his son. Besides, Celie was not the only female character of the novel to be physically abused. Sofia was first beaten by her husband who wanted her to obey his orders blindly as Celie obeyed her husband. Second she was beaten by the mayor and his police officers and then put in jail.

Furthermore, women were not allowed to love and choose their partners. However, these kinds of marriage arrangements which prevented women from choosing their partners affected both women and their families negatively. This is because women and their husbands were not linked by love, but by their fathers' interests. The end results was that most of the time women were considered as objects of pleasure.

The analysis of the color purple revealed that women overcame their oppression through sisterhood, a strong feeling of friendship and support among women who are involved in action to improve their rights. We learnt that the strong sisterhood between Celie, Nettie, Sofia and Shug Avery played a great role for their socio-economic freedom.

However, this research revealed the oppression that women underwent in American society of 1980s. This should serve as lesson so that today people should know that men and women must have the same rights and that everybody should bring their stone to build the society which is free from sexism.

\section{REFERENCES}

[1] Awad , F., Eldon , R. N., \& Pace, M. (n.d.). Questioning Liberal Feminist Theory: A case study of the American ERA. (International Studies Module Project). Retrieved February 18, 2022, from https://docplayer.net/20795944-Questioningliberal-feminist-theory-a-case-study-of-the-american-erainternational-studies-module-project.html
[2] Baga, A. (2010). Celie's Emancipation Process in Alice Walker's The Color Purple [Unpublished master's thesis]. Mentouri University.

[3] Brunell, L., \& Burkett, E. (2021, August 27). Feminism. Retrieved from Encyclopedia Britannica: https://www.britannica.com/topic/feminism

[4] Chowdhury, E. (2006). Global feminist theory's cul-de-sac. human architecture. Journal of Sociology of Self Knowledge, IV(special), 291-302.

[5] Crossman, A. (2020, February 25). Feminist Theory in Sociology. Retrieved from ThoughtCo.: https://www.thoughtco.com/feminist-theory-3026624

[6] De Vaus, D. A. (2001). Research Guides. Types of Research Designs. Retrieved from USC Libraries: https://libguides.usc.edu/writingguide/researchdesigns\#: :te $\mathrm{xt}=\mathrm{The} \% 20$ research $\% 20$ design $\% 20$ refers $\% 20$ to,measureme nt $\% 2 \mathrm{C} \% 20$ and $\% 20$ analysis $\% 20$ of $\% 20$ data.

[7] Dhivya, E. (2016). Women as Victims: An Analysis of Alice Walker's The Color Purple. Language in India, 16, 19302940.

[8] Egan, S. (1999). Women (Re) incorporated: A thesis examining the application of feminist theory to corporate structures and the legal framework of corporate law. Montreal: McGill University.

[9] Eidinger, A. (2020, December 15). Feminism. Retrieved from The Canadian Encyclopeadia: https://www.thecanadianencyclopedia.ca/en/article/feminis $\mathrm{m}$

[10] Encyclpeadia Americana. (1960). Vol 11.

[11] Goodwin University. (2022, January 28). English 102: Literature and Composition. Historical Criticism Resources. Retrieved from Hoffman Family Library: https://goodwin.libguides.com/c.php?g=950365\&p=742734 1

[12] Hasa. (2016, October 17). What is Psychological Criticism in Literature. Retrieved from Pediaa.com: https://pediaa.com/what-is-psychological-criticism-inliterature/\#: :text=Psychological\%20criticism\%20in\%20lite rature $\% 20$ refers,as $\% 20$ well $\% 20$ as $\% 20$ the $\% 20$ characters.

[13] Hsiao, P. L. (2008). Language, Gender, and Power in The Color Purple: Theories and approaches. Feng Chia Journal of Humanities and Social Sciences, 17, 93-120.

[14] Lewis, J. J. (2020, November 25). What Is Radical Feminism? Retrieved from ThoughtCo.: https://www.thoughtco.com/what-is-radical-feminism3528997

[15] Masuku , N. (2005). Perceived oppression of women in Zulu folklore: A feminist critique.

[16] Napikoski, L. (2020, February 6). Feminist Literary Criticism. Retrieved from ThoughtCo: https://www.thoughtco.com/feminist-literary-criticism3528960\#: :text=Feminist\%20literary\%20criticism\%20reco gnizes $\% 20$ that,happening $\% 20$ within $\% 20$ the $\% 20$ same $\% 20 \mathrm{w}$ ork.

[17] Radjuru, S. P. (2014). Concept of feminism in Alice Walker's 'The Color Purple': An analysis. International Multidisciplinary Research Journal, 1(X), 2321-5488. 
[18] Redmond, W. (2008). National Organisation for Women (NOW). Microsoft Student 2009 (DVD).

[19] Stevens, E. (2021, October 1). The 7 Most Useful Data Analysis Methods and Techniques. Retrieved from Careerfoundry: https://careerfoundry.com/en/blog/dataanalytics/data-analysis-techniques/\#what-is-data-analysis

[20] Theys, E. (2015). Black feminism in America. An overview and comparison of black feminism's destiny through literature and music up to Beyoncé. KU Leuven: MA Thesis.

[21] Torfs, E. (2008). Alice Walker's womanism: Theory and practice.

[22] Tyson, L. (2006). Critical theory today. A User-Friendly Guide (2nd ed.). New York: Routledge.

[23] Walker, A. (1982). The color purple. Ney York: Washington Square Press.

[24] Whiting, B. (2021, November 29). What is Data Analysis? Definition \& Overview. Retrieved from Study.com: https://study.com/academy/lesson/what-is-data-analysisdefinition-overview.html

[25] Woodford, K., Jackson, G., \& Gillard, P. (2003). Cambridge Advanced Learner's Dictionary. Cambridge University Press. 